\title{
Well-Ordered 3D Printed Cu/Pd-Decorated Catalysts for the Methanol Electrooxidation in Alkaline Solutions
}

\author{
Karolina Kołczyk-Siedlecka *(D), Dawid Kutyła (D), Katarzyna Skibińska, Anna Jędraczka, \\ Justyna Palczewska-Grela and Piotr Żabiński
}

check for updates

Citation: Kołczyk-Siedlecka, K.; Kutyła, D.; Skibińska, K.; Jędraczka, A.; Palczewska-Grela, J.; Żabiński, P. Well-Ordered 3D Printed $\mathrm{Cu} / \mathrm{Pd}$-Decorated Catalysts for the Methanol Electrooxidation in Alkaline Solutions. Technologies 2021, 9, 6. https://doi.org/10.3390/ technologies 9010006

Received: 27 November 2020 Accepted: 5 January 2021 Published: 8 January 2021

Publisher's Note: MDPI stays neutral with regard to jurisdictional clai$\mathrm{ms}$ in published maps and institutional affiliations.

Copyright: () 2021 by the authors. Licensee MDPI, Basel, Switzerland. This article is an open access article distributed under the terms and conditions of the Creative Commons Attribution (CC BY) license (https:// creativecommons.org/licenses/by/ $4.0 /)$.
Faculty of Non-Ferrous Metals, AGH University of Science and Technology, Mickiewicza 30, 30-059 Krakow, Poland; kutyla@agh.edu.pl (D.K.); kskib@agh.edu.pl (K.S.); kwiec@agh.edu.pl (A.J.); palczews@agh.edu.pl (J.P.-G.); zabinski@agh.edu.pl (P.Ż.)

* Correspondence: kkolczyk@agh.edu.pl

\begin{abstract}
In this article, a method for the synthesis of catalysts for methanol electrooxidation based on additive manufacturing and electroless metal deposition is presented. The research work was divided into two parts. Firstly, coatings were obtained on a flat substrate made of light-hardening resin dedicated to 3D printing. Copper was deposited by catalytic metallization. Then, the deposited $\mathrm{Cu}$ coatings were modified by palladium through a galvanic displacement process. The catalytic properties of the obtained coatings were analyzed in a solution of $0.1 \mathrm{M} \mathrm{NaOH}$ and $1 \mathrm{M}$ methanol. The influence of the deposition time of copper and palladium on the catalytic properties of the coatings was investigated. Based on these results, the optimal parameters for the deposition were determined. In the second part of the research work, 3D prints with a large specific surface were metallized. The elements were covered with a copper layer and modified by palladium, then chronoamperometric curves were determined. The application of the proposed method could allow for the production of elements with good catalytic properties, complex geometry with a large specific surface area, small volume and low weight.
\end{abstract}

Keywords: electroless metallization; catalysts; 3D printing

\section{Introduction}

Additive manufacturing is a technique that is increasingly used in new technologies [1-3]. The development of the digital revolution and 3D printing methods are changing the methods used for the production of functional objects. The use of 3D printing techniques allows for a quick transition from a digital model to a physical object. This ensures great flexibility in adapting a given geometry, as opposed to classical production methods like machining or casting for metallic parts or injection molding for plastics [4]. The advantage of this technique is the possibility of producing elements from materials such as plastic, metal or materials based on composites [5-7]. In addition, the modification of elements produced by the 3D printing method is also carried out, for example by covering them with metallic coatings. Thanks to the listed advantages and many possibilities, additive manufacturing has found many applications in many fields, for example in new technologies, medicine [8], catalysis [9-11] and electrochemistry [12-17].

Direct methanol fuel cells (DMFCs) are a promising solution for the problems of energy conversion. They are characterized by their small size, high energy conversion efficiency, low working temperature and the availability of methanol as fuel [18]. However, there are some limitations to introducing these cells into commercial markets. This is related to the low efficiency of the anode reaction due to the slow kinetics of methanol electrooxidation and the destruction of the electrode surfaces [19-21].

Good catalytic properties characterize noble metals such as Pt [22-24], Pd [25-27] and Ag [28-30]. However, these metals are expensive, and this limits their application possibilities. 
Copper is not a very popular catalyst for the electrooxidation process due to its high sensitivity and its reactivity towards oxygen. Nevertheless, there are research works focused on the application of this metal or its alloys. The catalytic properties of other metals, such as nickel [31], copper [32,33] and their alloys Ni-Cu [34,35] have been analyzed. Catalysts synthesized with noble metals, e.g., Pd-Ni [36-39], Pt-Ni [22,40], Pd-Cu [26,41-43], $\mathrm{Pt}-\mathrm{Cu}$ [44-47], have also been tested.

In the literature, catalytic coatings have often been deposited on conductive substrates such metals of graphite. Unfortunately, these materials often have a high density or they are more challenging to manufacture, especially with high-precision techniques. One of the solutions is the combination of additive manufacturing in terms of the possibility of obtaining complex geometry inside an element and the process of electroless deposition of metallic coatings [48]. In this paper, the results of research related to the synthesis of $\mathrm{Cu} /$ Pd coatings by electroless deposition on a resin substrate dedicated to 3D printing are presented. A novelty in this work is the development of electroless deposition on a complex surface. In our previous work [49,50], metallic electroless coatings were obtained on a flat surface. The obtained materials were analyzed in terms of catalytic properties in the methanol electrooxidation reaction. The presented experimental works are intended to develop a new type of catalysts.

\section{Materials and Methods}

In the experimental work, chemicals with analytical purity were used (ChemLand company, Poland). The main stage of research was the metallization of light-hardened resins. The substrate was made of FormLabs Form 2 (CadXpert company, Poland) resins (Clear and Gray) dedicated to the stereolithography (SLA) method. Both of them are characterized by chemical resistance, as described by the manufacturer $[51,52]$.

A liquid resin with a volume of $1 \mathrm{~mL}$ was dropped onto a glass substrate, and then cured using a UV lamp (power $48 \mathrm{~W}$ ) for $1 \mathrm{~min}$. The cured samples were washed in two stages in isopropanol for 20 min every step, according to the manufacturer's instructions. Then, they were washed with demineralized water and dried.

The cured samples were degreased in $5 \mathrm{wt} \% \mathrm{NaOH}$ solution at $70{ }^{\circ} \mathrm{C}$ for $10 \mathrm{~min}$ to remove other impurities from the surface. Then, the samples were washed in demineralized water and etched for $1 \mathrm{~min}$ at $70{ }^{\circ} \mathrm{C}$ in a chromic acid solution prepared as follows: $50 \mathrm{~g}$ $\mathrm{Cr}_{2} \mathrm{O}_{3}, 1500 \mathrm{~g} \mathrm{H}_{2} \mathrm{SO}_{4}, 250 \mathrm{~g} \mathrm{H}_{2} \mathrm{O}$. The chromium(IV) ions were neutralized and removed from the surface in $5 \mathrm{wt} \% \mathrm{HCl}$ and $5 \mathrm{wt} \% \mathrm{~K}_{2} \mathrm{~S}_{2} \mathrm{O}_{5}$ solution for $3 \mathrm{~min}$ at room temperature. Then, the samples were washed in demineralized water. The surface of the resin was activated by $\mathrm{Pd}(\mathrm{II})$ ions, the samples were placed into $1 \mathrm{~g} / \mathrm{L} \mathrm{PdCl}_{2}$ solution for $30 \mathrm{~min}$, and during this time the ions were adsorbed on resin surface. After this step, the samples were placed into freshly prepared $20 \mathrm{~g} / \mathrm{L} \mathrm{NaBH}_{4}$ solution to reduce the palladium ions.

After activation and reduction, the samples were thoroughly washed with demineralized water and placed into the metallization solution: $10 \mathrm{~g} / \mathrm{L} \mathrm{CuSO} \cdot 5 \mathrm{H}_{2} \mathrm{O}, 10 \mathrm{~g} / \mathrm{L}$ tartaric acid, $10 \mathrm{~mL} / \mathrm{L}$ formalin. The $\mathrm{pH}$ of the solution was modified by $\mathrm{NaOH}$, and it was equal to 12 . The temperature of solution was $40{ }^{\circ} \mathrm{C}$. The copper was deposited for 10 and $20 \mathrm{~min}$. Then, the samples were washed using demineralized water and placed for galvanic displacement into $2 \mathrm{~g} / \mathrm{L} \mathrm{PdCl}_{2}$ solution for $30 \mathrm{~s}$ to $5 \mathrm{~min}$. To compare the parameters of electroless deposited coatings with bulk material, the copper sheets were placed in the same solution for 1 and $5 \mathrm{~min}$.

All samples were tested electrochemically in $0.1 \mathrm{M} \mathrm{NaOH}+1 \mathrm{M}$ methanol solution in a three-electrode system at room temperature. The first electrode was a $\mathrm{Cu} / \mathrm{Pd}$ sample, the counter electrode was a $\mathrm{Pt}$ sheet, and as the reference electrode the saturated calomel electrode (SCE) was used. Cyclic voltammetry experiments were performed in the potential range between hydrogen and oxygen evolution with different scan rates.

Using SolidWorks 2018 SP 4.0 software and the FormLabs Form 2 3D printer, cylindershaped elements with a diameter of $2 \mathrm{~cm}$ and a height of $3 \mathrm{~cm}$ were designed and printed. The elements were characterized by large specific surface in relation to the dimensions. 
Similar to the previous samples, the elements were metallized by copper and decorated by palladium. Cyclic voltammogram measurements and a chronoamperometric curve were performed to evaluate catalytic properties. As was carried out previously, the elements were tested in $0.1 \mathrm{M} \mathrm{NaOH}+1 \mathrm{M} \mathrm{CH} 3 \mathrm{OH}$ solutions at room temperature in the threeelectrode system. The working electrode was the metallized element and the counter electrode was a Pt sheet. The cycling voltammograms were detected in the range from -1.0 to $1.5 \mathrm{~V}$ vs. SCE.

The obtained coatings were analyzed using scanning electron microscopy (SEM) with a JEOL -6000 Plus. The chemical composition and distribution of elements were determined using energy dispersive X-ray spectroscopy (EDS) analysis. The catalytical tests were performed using a BioLogic SP-200 potentiostat.

\section{Results and Discussion}

\subsection{Physical Characterization}

In this work, the concentration of copper and palladium in the obtained coatings was determined. For the selected sample, the analysis of $\mathrm{Cu}$ and $\mathrm{Pd}$ distribution was performed. In the main part of the research work, a series of catalytic tests for the methanol oxidation reaction were performed. SEM pictures of the coatings before and after catalytic tests were taken.

The elemental composition of the coatings obtained as a result of electroless (EL) copper deposition and galvanic displacement by palladium is shown in Figure 1. The copper concentration is marked in blue and the palladium concentration in red. The different types of obtained copper samples are marked with different symbol shapes. The change in Pd concentration was linear with the time of galvanic displacement. The palladium concentration was not dependent on the $\mathrm{Cu}$ deposition time. In both cases of $10 \mathrm{~min}$ and $20 \mathrm{~min}$ of electroless Cu metallization, the Pd content ranged from about $2.75 \%$ ( $30 \mathrm{~s}$ ) to $16.5 \%$ by mass ( $5 \mathrm{~min}$ ). In the case of Pd galvanic displacement on metallic copper, the palladium content after 5 min was equal to $15.12 \%$ by mass and on the $\mathrm{Cu}$ coatings this value was approx. $16.8 \%$ and $16.6 \%$ on the copper deposited for 10 and 20 min, respectively.

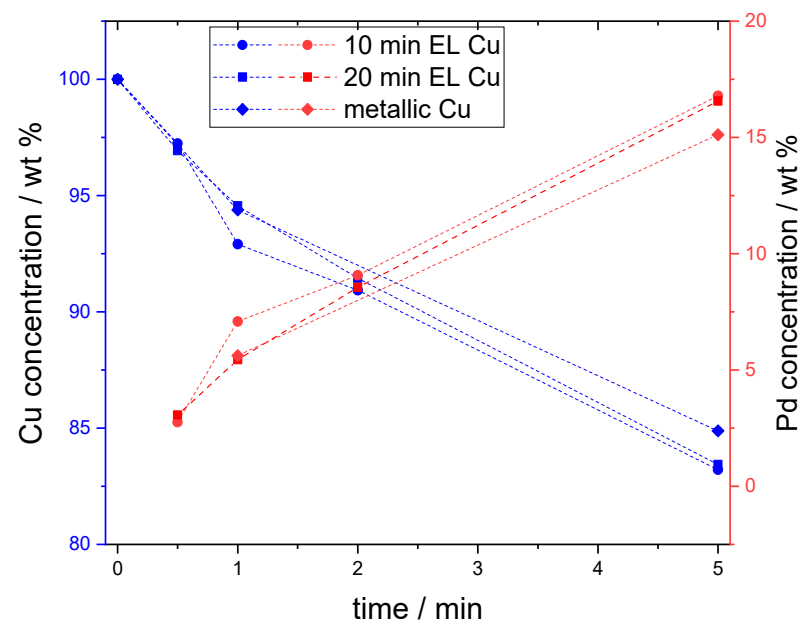

Figure 1. Composition of coatings depending on galvanic displacement time.

The SEM image taken for the coating obtained after $10 \mathrm{~min}$ of electroless $\mathrm{Cu}$ metallization and 5 min of galvanic exchange of palladium is presented in Figure 2. It can be seen that a smooth surface was obtained, and a slight precipitation can be observed. The mapping analysis showed that the distribution of Pd was homogeneous. 


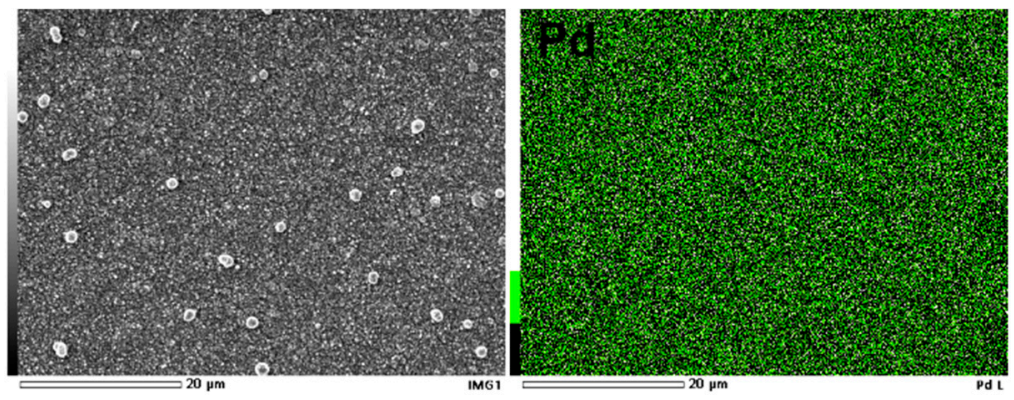

Figure 2. Mapping analysis of $\mathrm{Cu} / \mathrm{Pd}$ after $10 \mathrm{~min}$ of electroless deposition of $\mathrm{Cu}$ and $5 \mathrm{~min}$ of galvanic displacement Pd. Magnification: $\times 2000$.

\subsection{Electrooxidation of Methanol on the Cu/Pd-Decorated Coatings}

The methanol electrooxidation activity of $\mathrm{Cu}$ electrolessly deposited coatings modified by palladium was investigated in $0.1 \mathrm{M} \mathrm{NaOH}+1 \mathrm{M} \mathrm{CH}_{3} \mathrm{OH}$ solutions at room temperature using electrochemical techniques. Figure 3 presents cyclic voltammograms of materials, depending on electroless deposition of $\mathrm{Cu}$ and $\mathrm{Pd}$ galvanic displacement time (Figure $3 \mathrm{a}, \mathrm{b}$ ). As shown the presented cyclic voltammograms, a change in the anodic peak connected with the oxidation of methanol was observed. Depending on the time of Pd deposition by galvanic displacement and thus the different concentration, the maximum potential value changed, ranging from $0.8 \mathrm{~V}$ vs. SCE for $5 \mathrm{~min}$ Pd (about $16 \mathrm{wt}$. \%) to $1.2 \mathrm{~V}$ vs. SCE after 2 min of Pd (about $10 \mathrm{wt}$. \%) on the Cu substrate deposited for 10 min (Figure 3a). In the case of the $\mathrm{Cu}$ coatings deposited for $20 \mathrm{~min}$, the anode peaks varied to a lesser extent, from 1.2 to $1.36 \mathrm{~V}$ vs. SCE (Figure 3b), with the highest activity observed for the modification by $\mathrm{Pd}$ for $30 \mathrm{~s}$. To compare the catalytic properties, the diagrams for materials obtained on metallic copper are also presented (Figure 3c). Experiments were carried out on a copper substrate modified by palladium for $1 \mathrm{~min}$ and $5 \mathrm{~min}$. No significant difference was observed between the measurements carried out; the potential of the anode peak is $1.3 \mathrm{~V}$ vs. SCE (Figure 3c).

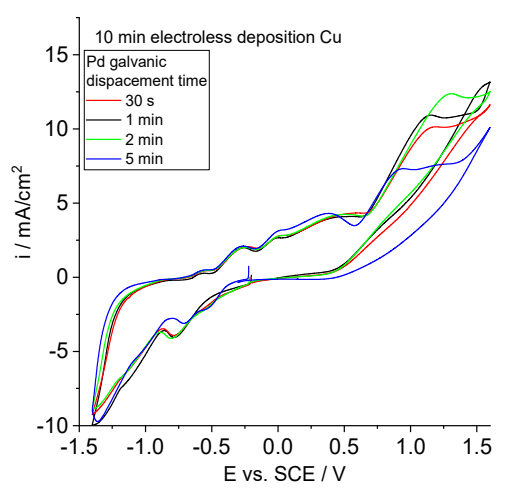

(a)

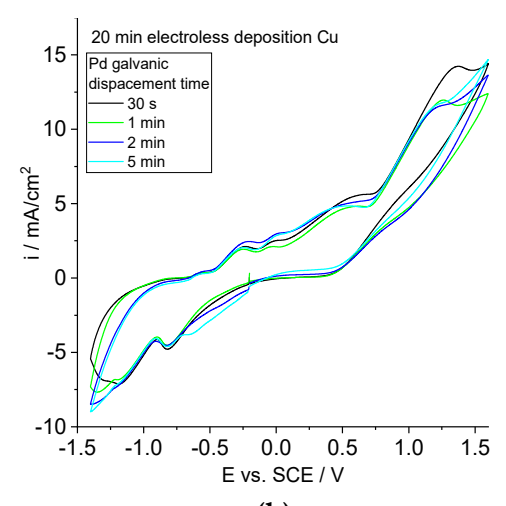

(b)

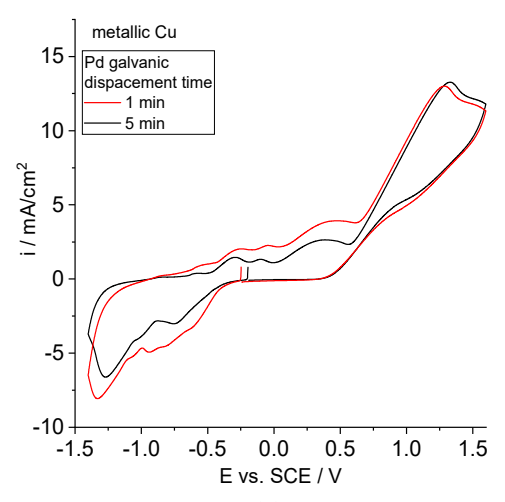

(c)

Figure 3. Cyclic voltammograms of $\mathrm{Cu} / \mathrm{Pd}$-decorated coatings depending on the substrate type and Pd galvanic displacement time. The substrates were as follows: $10 \mathrm{~min}(\mathbf{a}), 20 \mathrm{~min}(\mathbf{b})$ electrolessly deposition copper and metallic copper (c). The measurements were performed in $0.1 \mathrm{M} \mathrm{NaOH}+1 \mathrm{M}$ methanol solution, scan rate: $50 \mathrm{mV} / \mathrm{s}$.

The cyclic voltammogram curves for different scan rates were determined. Figure 4 shows them for two exemplary samples-the coatings obtained in $20 \mathrm{~min} \mathrm{Cu}$ electroless metallization $+30 \mathrm{~s}$ and $5 \mathrm{~min}$ Pd galvanic displacement. As the scan rate increases, the anode peak from the oxidation of methanol increases. The same tendency was shown in all the analyses. Cyclic voltammograms of the remaining samples depending on the scan rates are presented in the Supplementary Materials (Figures S1-S6). 


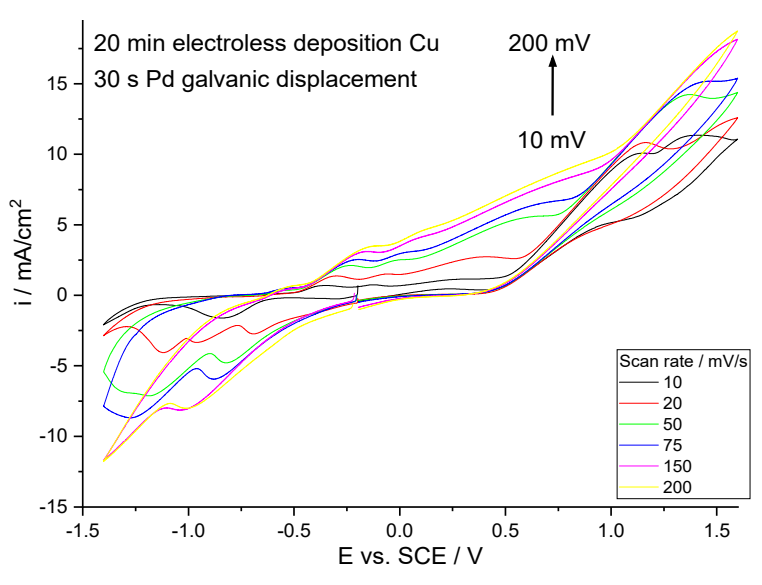

(a)

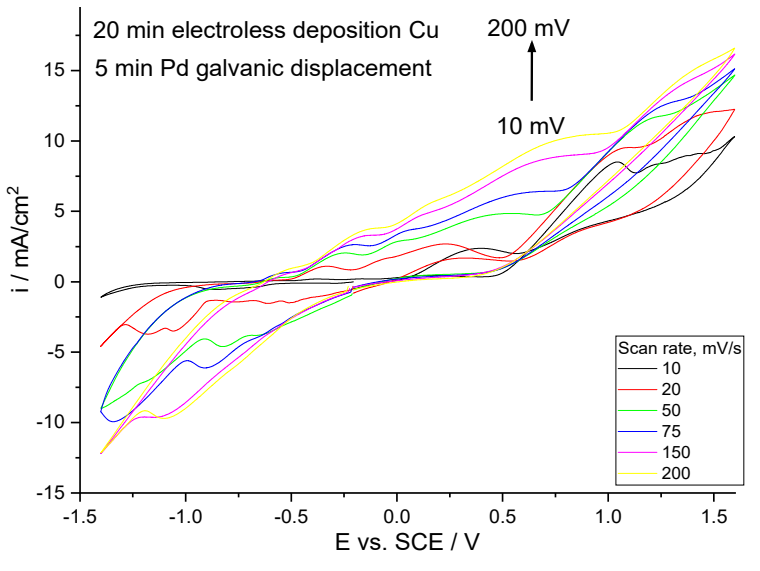

(b)

Figure 4. Cyclic voltammograms of obtained coatings in $0.1 \mathrm{M} \mathrm{NaOH}+1 \mathrm{M}$ methanol solution at different scan rates. The deposition parameters: 20 min electroless deposition of $\mathrm{Cu}$, modification by palladium for $30 \mathrm{~s} \mathrm{(a)} \mathrm{and} 5 \mathrm{~min}(\mathbf{b})$.

Based on the cyclic voltammogram curves presented in Figure 4 and in the Supplementary Materials (Figures S5 and S6), the change in the relationship between the current density and the square root of the scan rate was determined (Figure 5a). This relationship has been shown to be linear, therefore it can be concluded that the methanol electrooxidation reaction takes place through diffusion control [44]. For all cases, a high correlation coefficient $R^{2}$ was obtained. Figure $5 \mathrm{~b}$ shows that the potential changed linearly with the logarithm of the scan rate, suggesting that methanol oxidation on the surfaces is an irreversible process [44].

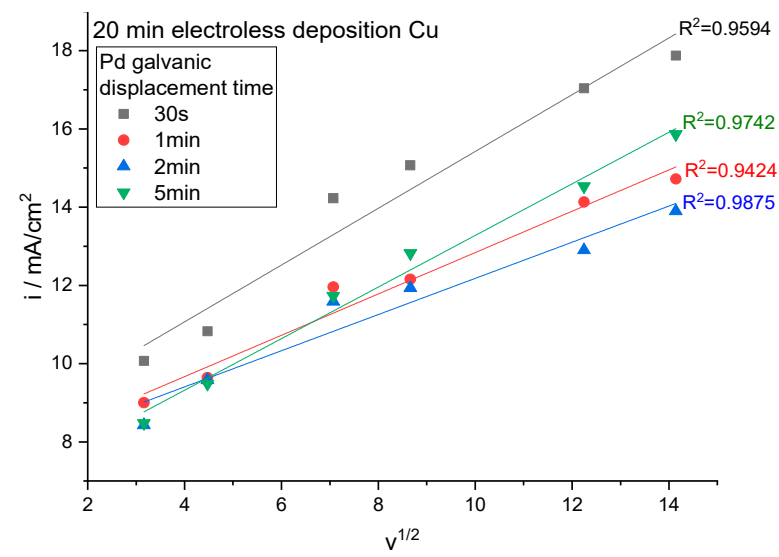

(a)

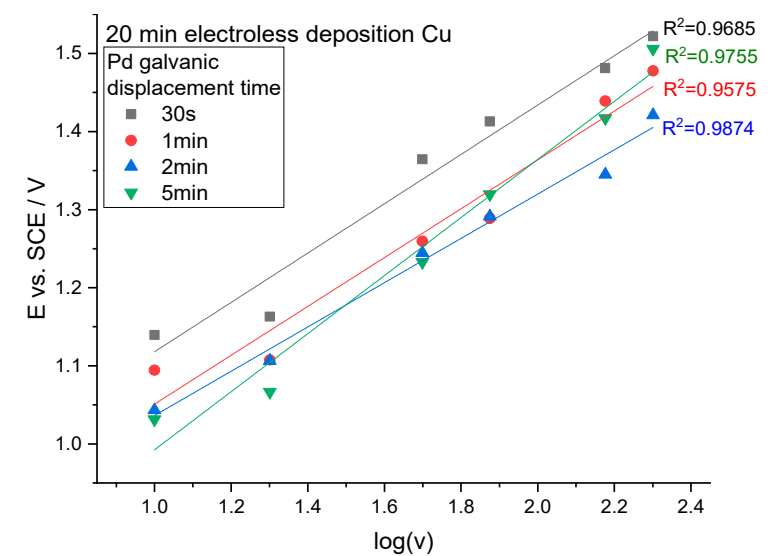

(b)

Figure 5. Characteristics of the coatings depending on the Pd galvanic displacement time. Change in anodic peak current with the square roots of scan rate (a), change in anodic peak potential with logarithm of scan rate (b). The copper was deposited for $20 \mathrm{~min}$ and modified by Pd.

The SEM pictures of the coatings prepared for electrochemical analysis and after catalytic tests are presented in Figure 6. The $\mathrm{Cu}$ coatings obtained electrolessly were characterized by continuity. In the case of copper deposited for $10 \mathrm{~min}$, small holes were observed. Small irregularly shaped or spherical precipitates were observed on the coating surfaces. Precipitations came from the electroless copper deposition process, and not from Pd galvanic displacement, which can be observed in the mapping analysis (Figure 2) and in comparison to the $\mathrm{Cu}$ coatings obtained after $20 \mathrm{~min}$ (Figure 6). In the case of $\mathrm{Cu}$ deposited for $20 \mathrm{~min}$, the coatings had a homogeneous morphology and small crystalline coatings 
were observed. After catalytic tests, in the case of $\mathrm{Cu} / \mathrm{Pd}$ materials obtained after $10 \mathrm{~min}$ of electroless copper deposition, the destruction of the coatings was clearly visible.
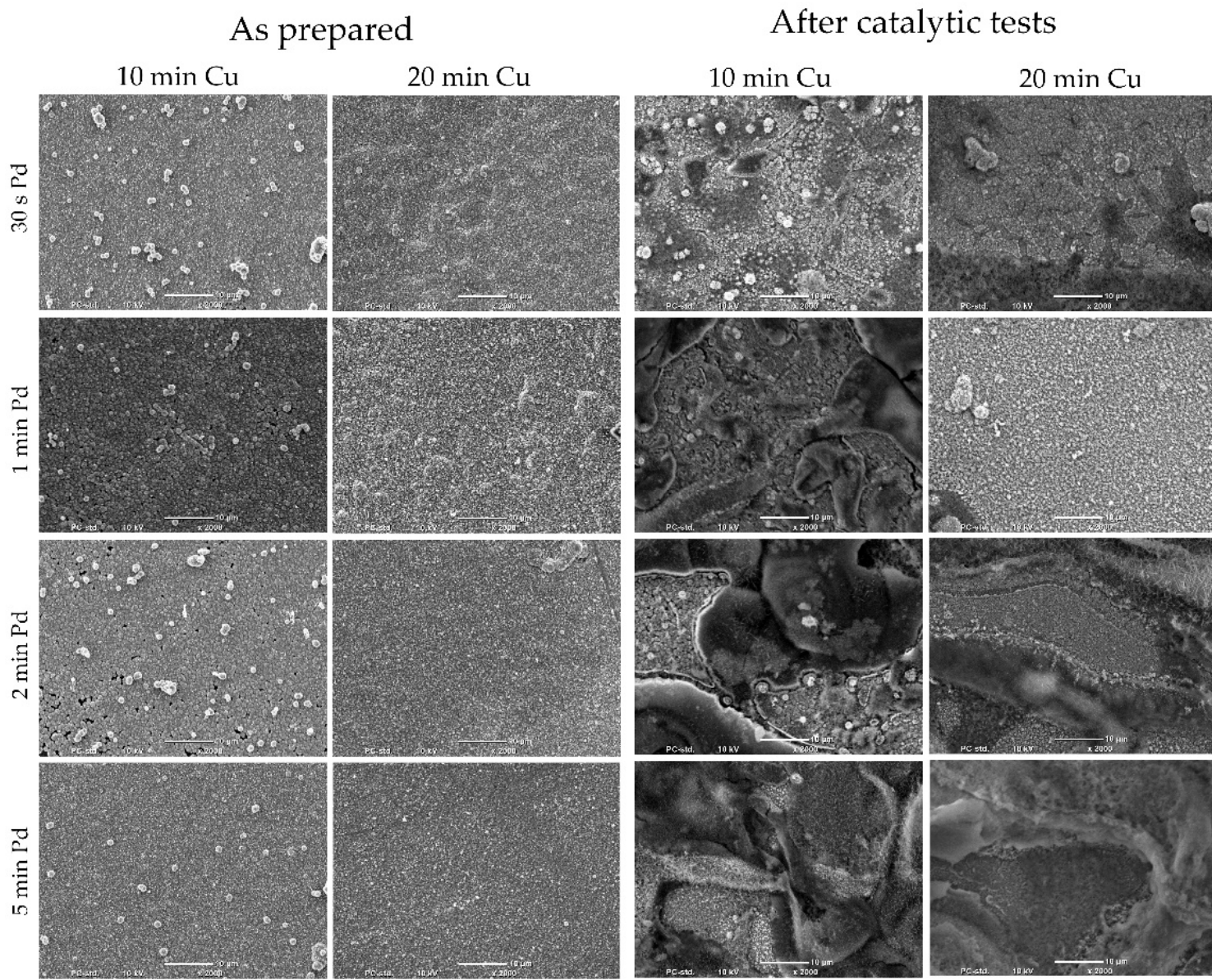

Figure 6. SEM pictures of electroless-deposited $\mathrm{Cu}$ modified by $\mathrm{Pd}$, depending on copper deposition and galvanic displacement time as prepared and after electrochemical tests, magnification $\times 2000$.

In some cases (e.g., after $30 \mathrm{~s}$ of Pd galvanic displacement) characteristic precipitations were still visible. Coatings based on $\mathrm{Cu}$ deposited for $20 \mathrm{~min}$ were characterized by less damage of the coatings. After the tests, the coatings were still stable and showed good adhesion. The bluish discoloration of the precipitate was clearly visible, indicating copper oxidation.

To assess the quality of coatings prepared on metallic copper, the SEM pictures were taken (Figure 7). Slight cracks were visible on the surface, and slight irregular precipitations were visible after 5 min of palladium deposition. Surface destruction was observed after catalytic tests-in the case of the coating deposited after $1 \mathrm{~min}$ with Pd galvanic displacement, the size of cracks on the surface increased. In the case of a higher palladium content, most of the precipitates from the surface disappeared. As with the resin-deposited coatings, it was observed that the coatings were oxidized after the tests. 


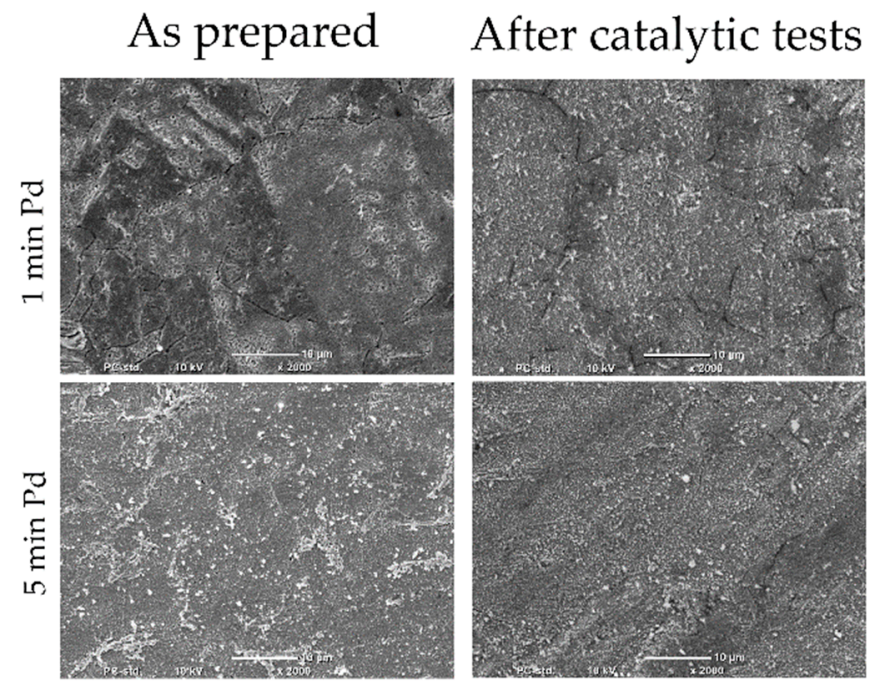

Figure 7. SEM pictures of metallic $\mathrm{Cu}$ modified by $\mathrm{Pd}$, depending on galvanic displacement time as prepared and after electrochemical tests, magnification $\times 2000$.

\subsection{Methanol Electrooxidation on 3D Printed Elements}

A prototype of a catalyst for the electrooxidation of methanol in basic solutions was made, and its design is presented in Figure 8. The cylindrical prints were designed based on common geometry [11]. Round holes were made parallel to and perpendicular to the cylinder's axis.

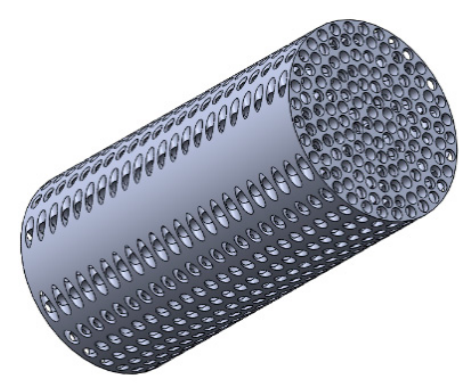

(a)

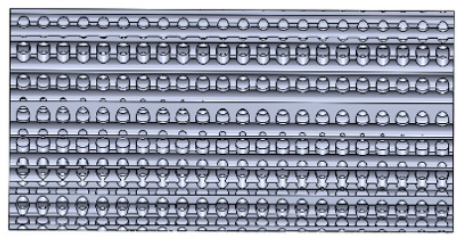

(b)

Figure 8. Drawing (a) and cross-section (b) of the catalyst made in the SolidWorks software.

Figure 8 shows the digital design of the element. The cross-section shown in Figure $8 \mathrm{~b}$ shows that the element is characterized by high porosity, thanks to which it was possible to obtain a large specific surface, which is equal to $230 \mathrm{~cm}^{2}$.

Two elements were prepared and metallized by copper according to the procedure described previously; the $\mathrm{Cu}$ metallization time was equal to $20 \mathrm{~min}$. Then, the metallized elements were placed into $2 \mathrm{~g} / \mathrm{L} \mathrm{PdCl}_{2}$ solutions for 2 and $5 \mathrm{~min}$. The concentration of palladium in $\mathrm{Cu} / \mathrm{Pd}$ coatings was determined by EDS.

The anodic peak was determined from the cyclic voltammogram curves presented in Figure 9a. The obtained potential was chosen for potentiostatic measurements, which were performed over $15 \mathrm{~min}$ in the same solutions. In case of the coatings modified by Pd for 5 min, the maximum determined potential was equal to $1.3 \mathrm{~V} \mathrm{vs}$. SCE. An anode potential of $1.05 \mathrm{~V}$ vs. SCE was observed on the curve of the coating deposited for $20 \mathrm{~min}$ with $\mathrm{Cu}$ and modified for $2 \mathrm{~min}$ by Pd. For the chronoamperometry curves, the stability of the current over time was observed (Figure 9b). After a certain period, both curves tended to plateau, when the Pd concentration was near $20 \%$ and over $10 \%$ by mass. 


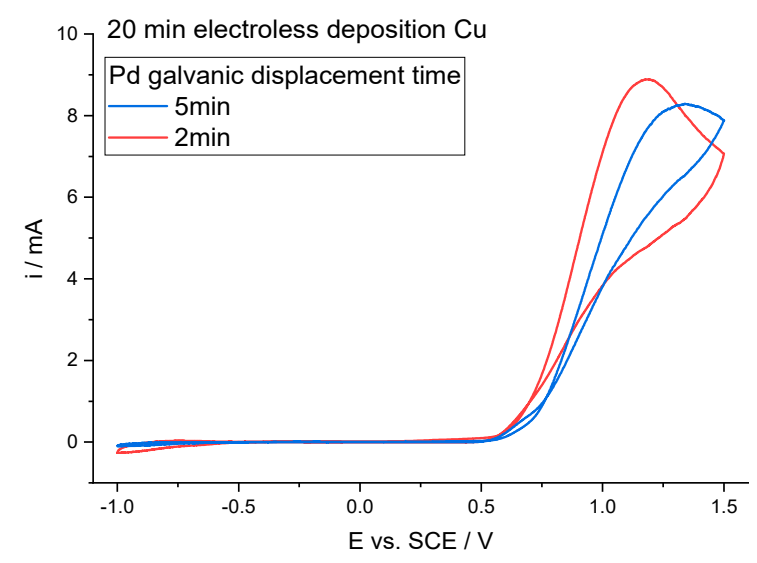

(a)

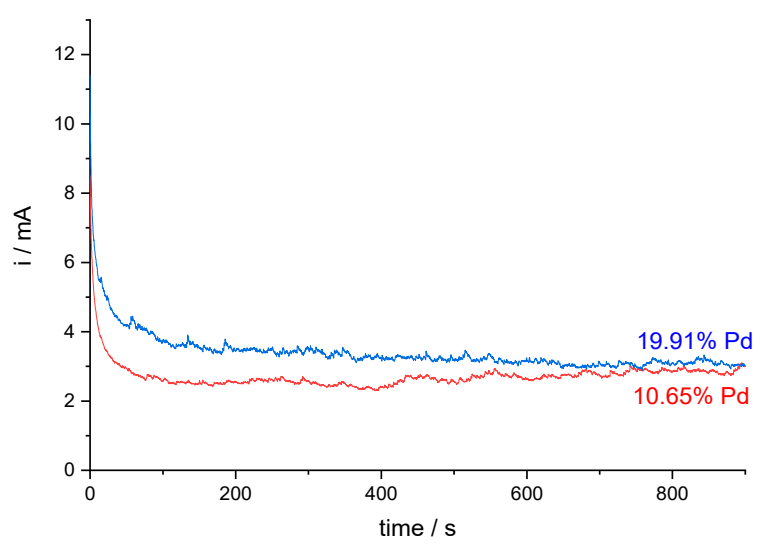

(b)

Figure 9. Cyclic voltammograms (a) and chronoamperometry (b) of metallized 3D prints. The Cu substrate was deposited in $20 \mathrm{~min}$ and modified by $\mathrm{Pd}$ in galvanic displacement in 2 and $5 \mathrm{~min}$.

Figure 10 presents SEM pictures of $\mathrm{Cu} / \mathrm{Pd}$ coatings obtained on 3D prints, depending on the modification time with palladium, as prepared and after catalytic tests. The coatings were characterized by a similar morphology, regardless of the palladium galvanic displacement time. Fewer minor precipitates were also observed for the shorter time of Pd deposition. The coatings did not deteriorate after catalytic tests; they remained compact and adhered to the substrate. Fewer precipitates on the surface were observed.

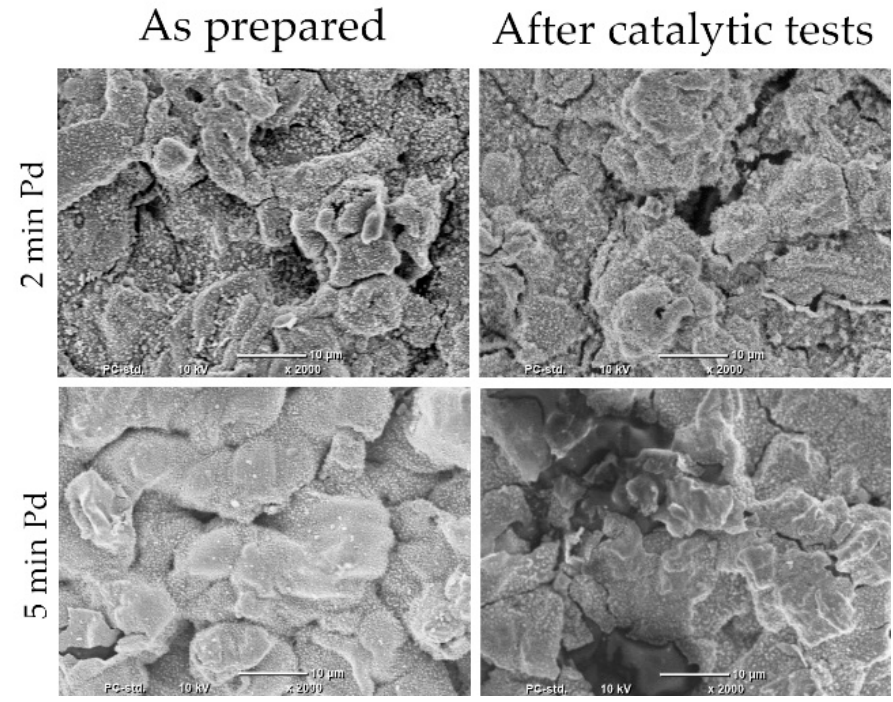

Figure 10. SEM pictures of coatings deposited on 3D prints as prepared and after catalytic tests, magnification $\times 2000$.

\section{Conclusions}

The aim of this work was to develop a prototype of a catalyst intended for direct methanol fuel cells. A catalyst synthesis based on 3D printing and electroless copper deposition was proposed.

Metallic $\mathrm{Cu}$ coatings were modified by palladium through the galvanic displacement process. In the first stage, $\mathrm{Cu} / \mathrm{Pd}$ coatings on a flat substrate were synthesized. The obtained coatings were characterized by a homogeneous distribution of elements on their surface. Cyclic voltammogram curves were obtained to determine the catalytic properties of $\mathrm{Cu} / \mathrm{Pd}$ coatings. The coatings formed on the $\mathrm{Cu}$ substrate deposited for $20 \mathrm{~min}$ were characterized by smaller anode peak potential differences, depending on composition. By determining the linear relationship of currents in the anode peak as a function of the 
element from the scan rate and the potential from $\log (\mathrm{v})$, it was determined that the reaction was diffusion-controlled and irreversible. Based on the SEM pictures, it was determined that coatings obtained on electroless copper deposition for $10 \mathrm{~min}$ are porous and unstable-after catalytic tests, the destruction of the coatings was visible. Coatings based on 20 min EL Cu were less damaged.

On the basis of the results obtained, the metallization parameters of substrates constituting 3D prints with a large specific surface were determined. Composition, cyclic voltammograms and chronoamperometry curves were determined and SEM pictures of the coatings were taken before and after the electrochemical tests. It was found that the coatings were not significantly damaged by the applied potential. Using these techniques, a 3D printed catalyst model was pre-developed.

Supplementary Materials: The following are available online at https:/ / www.mdpi.com/2227-708 0/9/1/6/s1, Figure S1: Cyclic voltammograms of 10 min electroless (EL) copper + 30 s Pd in $0.1 \mathrm{M}$ $\mathrm{NaOH}+1 \mathrm{M}$ methanol solution at different scan rates; Figure S2: Cyclic voltammograms of $10 \mathrm{~min}$ EL copper $+1 \mathrm{~min} \mathrm{Pd}$ in $0.1 \mathrm{M} \mathrm{NaOH}+1 \mathrm{M}$ methanol solution at different scan rates; Figure S3: Cyclic voltammograms of $10 \mathrm{~min}$ EL copper $+2 \min \mathrm{Pd}$ in $0.1 \mathrm{M} \mathrm{NaOH}+1 \mathrm{M}$ methanol solution at different scan rates; Figure S4: Cyclic voltammograms of $10 \mathrm{~min}$ EL copper $+5 \mathrm{~min}$ Pd in $0.1 \mathrm{M}$ $\mathrm{NaOH}+1 \mathrm{M}$ methanol solution at different scan rates; Figure S5: Cyclic voltammograms of 20 min EL copper $+1 \mathrm{~min} \mathrm{Pd}$ in $0.1 \mathrm{M} \mathrm{NaOH}+1 \mathrm{M}$ methanol solution at different scan rates; Figure S6: Cyclic voltammograms of $20 \mathrm{~min}$ EL copper $+2 \mathrm{~min} \mathrm{Pd}$ in $0.1 \mathrm{M} \mathrm{NaOH}+1 \mathrm{M}$ methanol solution at different scan rates.

Author Contributions: Conceptualization, K.K.-S. and D.K.; methodology, K.K.-S. and A.J.; software, K.S.; validation, K.K.-S., P.Ż. and J.P.-G.; resources, K.K.-S.; data curation, K.K.-S.; writing-original draft preparation, K.K.-S.; writing-review and editing, D.K. and J.P.-G.; supervision, P.Ż. All authors have read and agreed to the published version of the manuscript.

Funding: This research was funded by Polish National Science Centre, grant number No UMO2017/25/N/ST8/01721. The authors are grateful to Faculty of Non-Ferrous Metals for providing space and materials for research.

Institutional Review Board Statement: Not applicable.

Informed Consent Statement: Not applicable.

Data Availability Statement: Data is contained within the article or supplementary material.

Conflicts of Interest: The authors declare no conflict of interest. The funders had no role in the design of the study; in the collection, analyses or interpretation of data; in the writing of the manuscript, or in the decision to publish the results.

\section{References}

1. Zhang, F.; Wei, M.; Viswanathan, V.V.; Swart, B.; Shao, Y.; Wu, G.; Zhou, C. 3D printing technologies for electrochemical energy storage. Nano Energy 2017, 40, 418-431. [CrossRef]

2. Jiménez, M.; Romero, L.; Dom, I.A.; Espinosa, M.D.M.; Domínguez, M. Additive Manufacturing Technologies: An Overview about 3D Printing Methods and Future Prospects. Complexity 2019, 2019, 9656938. [CrossRef]

3. Yap, Y.L.; Sing, S.L.; Yeong, W.Y. A review of 3D printing processes and materials for soft robotics. Rapid Prototyp. J. 2020, 26/8, 1345-1361. [CrossRef]

4. Attaran, M. The rise of 3-D printing: The advantages of additive manufacturing over traditional manufacturing. Bus. Horiz. 2017, 60, 677-688. [CrossRef]

5. Ngo, T.D.; Kashani, A.; Imbalzano, G.; Nguyen, K.T.Q.; Hui, D. Additive manufacturing (3D printing): A review of materials, methods, applications and challenges. Compos. Part B 2018, 143, 172-196. [CrossRef]

6. Bourell, D.; Pierre, J.; Leu, M.; Levy, G.; Rosen, D.; Beese, A.M.; Clare, A. Materials for additive manufacturing. CIRP Ann. Manuf. Technol. 2017, 66, 659-681. [CrossRef]

7. Ma, C.; He, C.; Wang, W.; Yao, X.; Yan, L.; Hou, F. Metal-doped polymer-derived SiOC composites with inorganic metal salt as the metal source by digital light processing 3D printing. Virtual Phys. Prototyp. 2020, 15, 294-306. [CrossRef]

8. Javaid, M.; Haleem, A.; Javaid, M.; Haleem, A. Additive manufacturing applications in medical cases: A literature based review. Alex. J. Med. 2019, 54, 411-422. [CrossRef] 
9. Lind, A.; Vistad, Ø.; Sunding, M.F.; Andreassen, K.A.; Ha, J.; Grande, C.A. Multi-purpose structured catalysts designed and manufactured by 3D printing. Mater. Des. 2020, 187, 1-8. [CrossRef]

10. Parra-cabrera, C.; Achille, C.; Kuhn, S.; Ameloot, R.; Parra-cabrera, C. 3D printing in chemical engineering and catalytic technology: Structured catalysts, mixers and reactors. Chem. Soc. Rev. 2017, 47, 209-230. [CrossRef]

11. Bogdan, E.; Michorczyk, P. 3D Printing in Heterogeneous Catalysis—The State of the Art. Materials 2020, 13, 4534. [CrossRef] [PubMed]

12. Rocha, D.P.; Oliveira, P.R.; Janegitz, B.C.; Bonacin, J.A.; Richter, E.M.; Munoz, R.A.A. Additive-manufactured (3D-printed) electrochemical sensors: A critical review. Anal. Chim. Acta 2020, 1118, 73-91. [CrossRef]

13. Hong, E.; Ho, Z.; Ambrosi, A.; Pumera, M. Additive manufacturing of electrochemical interfaces: Simultaneous detection of biomarkers. Appl. Mater. Today 2018, 12, 43-50. [CrossRef]

14. Cheng, T.S.; Zafir, M.; Nasir, M.; Ambrosi, A.; Pumera, M. 3D-printed metal electrodes for electrochemical detection of phenols. Appl. Mater. Today 2017, 9, 212-219. [CrossRef]

15. Lee, C.; Taylor, A.C.; Nattestad, A.; Beirne, S.; Wallace, G.G. 3D Printing for Electrocatalytic Applications. Joule 2019, 3, 1835-1849. [CrossRef]

16. Tubío, C.R.; Azuaje, J.; Escalante, L.; Coelho, A.; Guitián, F.; Sotelo, E.; Gil, A. 3D printing of a heterogeneous copper-based catalyst. J. Catal. 2016, 334, 110-115. [CrossRef]

17. Zhu, C.; Liu, T.; Qian, F.; Chen, W.; Chandrasekaran, S.; Yao, B.; Song, Y.; Duoss, E.B.; Kuntz, J.D.; Spadaccini, C.M.; et al. 3D printed functional nanomaterials for electrochemical energy storage. Nano Today 2017, 15, 107-120. [CrossRef]

18. Yuda, A.; Ashok, A.; Kumar, A. A comprehensive and critical review on recent progress in anode catalyst for methanol oxidation reaction. Catal. Rev. 2020. [CrossRef]

19. Jorissen, L.; Gogel, V. Direct Methanol: Overview. In Encyclopedia of Electrochemical Power Sources; Elsevier: London, UK, 2009; pp. 370-380.

20. Samimi, F.; Rahimpour, M.R. Direct Methanol Fuel Cell. In Methanol; Elsevier B.V.: Amsterdam, The Netherlands, 2018; pp. 381-397; ISBN 9780444639035.

21. Liu, H.; Song, C.; Zhang, L.; Zhang, J.; Wang, H.; Wilkinson, D.P. A review of anode catalysis in the direct methanol fuel cell. J. Power Sources 2006, 155, 95-110. [CrossRef]

22. Nagashree, K.L.; Raviraj, N.H.; Ahmed, M.F. Carbon paste electrodes modified by Pt and Pt-Ni microparticles dispersed in polyindole film for electrocatalytic oxidation of methanol. Electrochim. Acta 2010, 55, 2629-2635. [CrossRef]

23. Al-saidi, W.S.; Jahdaly, B.A.A.L.; Awad, M.I. Methanol electro-oxidation at platinum electrod: In situ recovery of CO poisoned platinum electrode. Int. J. Electrochem. Sci. 2020, 15, 1830-1839. [CrossRef]

24. Ejigu, A.; Johnson, L.; Licence, P.; Walsh, D.A. Electrocatalytic oxidation of methanol and carbon monoxide at platinum in protic ionic liquids. Electrochem. Commun. 2012, 23, 122-124. [CrossRef]

25. Carlos, J.; Gómez, C.; Moliner, R.; Lázaro, M.J. Palladium-Based Catalysts as Electrodes for Direct Methanol Fuel Cells: A Last Ten Years Review. Catalysts 2016, 6, 130. [CrossRef]

26. Yan, B.; Xu, H.; Zhang, K.; Li, S.; Wang, J.; Shi, Y.; Du, Y. Cu assisted synthesis of self-supported PdCu alloy nanowires with enhanced performances toward ethylene glycol electrooxidation. Appl. Surf. Sci. 2018, 434, 701-710. [CrossRef]

27. Roy, S.; Mukherjee, P. Palladium and palladium-copper alloy nano particles as superior catalyst for electrochemical oxidation of methanol for fuel cell applications. Int. J. Hydrogen Energy 2016, 41, 17072-17083. [CrossRef]

28. Shivakumar, M.S.; Krishnamurthy, G.; Ravikumar, C.R.; Bhatt, A.S. Decoration of silver nanoparticles on activated graphite substrate and their electrocatalytic activity for methanol oxidation. J. Sci. Adv. Mater. Devices 2019, 4, 290-298. [CrossRef]

29. Rinco, A.; Gutie, C. Electrooxidation of methanol on silver in alkaline medium. J. Electroanal. Chem. 2000, 495, 71-78.

30. Nocun, M.; Jabłon, M. Silver-Alumina Catalysts for Low-Temperature Methanol Incineration. Catal. Lett. 2016, 146, 937-944. [CrossRef]

31. Salci, A.; Altunbas, E.; Solmaz, R. Methanol electrooxidation at nickel-modified rhodanine self assembled monolayer films: A new class of multilayer electrocatalyst. Int. J. Hydrog. Energy 2019, 44, 14228-14234. [CrossRef]

32. Heli, H.; Jafarian, M.; Mahjani, M.G.; Gobal, F. Electro-oxidation of methanol on copper in alkaline solution. Electrochim. Acta 2004, 49, 4999-5006. [CrossRef]

33. Chen, G.; Pan, Y.; Lu, T.; Wang, N.; Li, X. Highly catalytical performance of nanoporous copper for electro-oxidation of methanol in alkaline media. Mater. Chem. Phys. 2018, 218, 108-115. [CrossRef]

34. Danaee, I.; Jafarian, M.; Forouzandeh, F.; Gobal, F.; Mahjani, M.G. Electrocatalytic oxidation of methanol on Ni and NiCu alloy modified glassy carbon electrode. Int. J. Hydrog. Energy 2008, 33, 4367-4376. [CrossRef]

35. Mao, Y.; Chen, C.; Fu, J.; Lai, T.; Lu, F.; Tsai, Y. Electrodeposition of nickel-Copper on titanium nitride for methanol electrooxidation. Surf. Coat. Technol. 2018, 350, 949-953. [CrossRef]

36. Kamyabi, M.A.; Jadali, S. A sponge like Pd arrays on Ni foam substrate: Highly active non-platinum electrocatalyst for methanol oxidation in alkaline media. Mater. Chem. Phys. 2021, 257, 123626. [CrossRef]

37. Qiu, C.; Shang, R.; Xie, Y.; Bu, Y.; Li, C.; Ma, H. Electrocatalytic activity of bimetallic Pd-Ni thin films towards the oxidation of methanol and ethanol. Mater. Chem. Phys. 2010, 120, 323-330. [CrossRef]

38. Carvalho, L.L.; Colmati, F.; Tanaka, A.A. Nickel-palladium electrocatalysts for methanol, ethanol, and glycerol oxidation reactions. Int. J. Hydrogen Energy 2017, 42, 16118-16126. [CrossRef] 
39. Maity, S.; Harish, S.; Eswaramoorthy, M. Controlled galvanic replacement of Ni in Ni(OH)2 by Pd: A method to quantify metallic $\mathrm{Ni}$ and to synthesize bimetallic catalysts for methanol oxidation. Mater. Chem. Phys. 2019, 221, 377-381. [CrossRef]

40. Habibi, B.; Dadashpour, E. Carbon-ceramic supported bimetallic Pt e Ni nanoparticles as an electrocatalyst for electrooxidation of methanol and ethanol in acidic media. Int. J. Hydrogen Energy 2012, 38, 5425-5434. [CrossRef]

41. Yin, Z.; Zhou, W.; Gao, Y.; Ma, D.; Kiely, C.J. Supported Pd-Cu Bimetallic Nanoparticles That Have High Activity for the Electrochemical Oxidation of Methanol. Chem. Eur. J. 2012, 18, 4887-4893. [CrossRef]

42. Na, H.; Zhang, L.; Qiu, H.; Wu, T.; Chen, M.; Yang, N.; Li, L.; Xing, F.; Gao, J. A two step method to synthesize palladium e copper nanoparticles on reduced graphene oxide and their extremely high electrocatalytic activity for the electrooxidation of methanol and ethanol. J. Power Sources 2015, 288, 160-167. [CrossRef]

43. Zhang, Z.; Zhang, C.; Sun, J.; Kou, T.; Zhao, C. Ultrafine nanoporous Cu-Pd alloys with superior catalytic activities towards electro-oxidation of methanol and ethanol in alkaline media. RSC Adv. 2012, 2, 11820-11828. [CrossRef]

44. Poochai, C.; Veerasai, W.; Somsook, E.; Dangtip, S. The influence of copper in dealloyed binary platinum-copper electrocatalysts on methanol electroxidation catalytic activities. Mater. Chem. Phys. 2015, 163, 317-330. [CrossRef]

45. Poochai, C. Highly active dealloyed Cu@Pt core-shell electrocatalyst towards 2-propanol electrooxidation in acidic solution. Appl. Surf. Sci. 2017, 396, 1793-1801. [CrossRef]

46. Long, X.; Yin, P.; Lei, T.; Wang, K.; Zhan, Z. Methanol electro-oxidation on Cu@Pt/C core-shell catalyst derived from Cu-MOF. Appl. Catal. B Environ. 2020, 260, 118187. [CrossRef]

47. Lee, J.; Han, S.; Kwak, D.; Kim, M.; Lee, S.; Park, J.; Choi, I.; Park, H.; Park, K. Porous Cu-rich@Cu3Pt alloy catalyst with a low Pt loading for enhanced electrocatalytic reactions. J. Alloys Compd. 2017, 691, 26-33. [CrossRef]

48. Bernasconi, R.; Credi, C.; Tironi, M.; Levi, M.; Magagnin, L. Electroless Metallization of Stereolithographic Photocurable Resins for 3D Printing of Functional Microdevices. J. Electrochem. Soc. 2017, 164, B3059-B3066. [CrossRef]

49. Kolczyk, K.; Zborowski, W.; Kutyla, D.; Kwiecinska, A.; Kowalik, R.; Zabinski, P. Investigation of Two-Step Metallization Process of Plastic 3d Prints Fabricated by SLA Method. Arch. Metall. Mater. 2018, 63, 1031-1036. [CrossRef]

50. Kołczyk-Siedlecka, K.; Skibińska, K.; Kutyła, D.; Kwiecińska, A.; Kowalik, R.; Żabiński, P. Influence of Magnetic Field on Electroless Metallization of 3d Prints by Copper and Nickel. Arch. Metall. Mater. 2019, 64, 17-22. [CrossRef]

51. KMK Regulatory Services Inc. Clear Photoreactive Resin for Formlabs 3D Printers Karta Charakterystyki. Available online: https:/ / sklep.3dl.tech/wp-content/uploads/2017/12/Clear_Formlabs-SDS-EU-Polish.pdf (accessed on 15 June 2019).

52. KMK Regulatory Services Inc. Grey Photoreactive Resin for Formlabs 3D Printers Karta Charakterystyki. Available online: https:/ /sklep.3dl.tech/wp-content/uploads/2017/12/Grey_Formlabs-SDS-EU-Polish.pdf (accessed on 15 June 2019). 